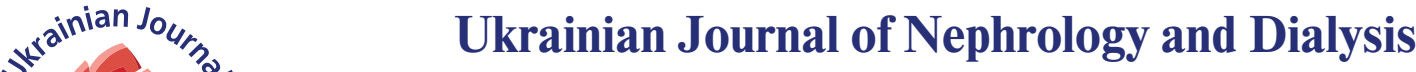

Scientific and Practical, Medical Journal

$z_{0}$

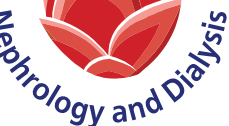

Founders:

- State Institution «Institute of Nephrology NAMS of Ukraine»

- National Kidney Foundation of Ukraine

ISSN 2304-0238;

eISSN 2616-7352

Journal homepage: https://ukrjnd.com.ua

\section{Research Article}

doi: 10.31450/ukrjnd.3(59).2018.06

\section{Dudar, V. Savchuk, O. Loboda, Y. Gonchar, I. Shifris, V. Krot}

The level of prolactin in patient with CKD V stage, which are treated with hemodialysis

SI "Institute of nephrology NAMS of Ukraine", Kyiv

\section{Citation:}

Article history:

Received 26 July 2018

Received in revised form

13 August 2018

Accepted 20 August 2018
Dudar I, Savchuk V, O. Loboda, Y. Gonchar, I. Shifris, V. Krot. The level of prolactin in patient with CKD $\vee$ stage, which are treated with hemodialysis. Ukr J Nephr Dial. 2018;3(59):38-43. doi: 10.31450/ukrjnd.3(59).2018.06

Abstract. The prevalence of hyperprolactinemia in patients treated with hemodialysis (HD) is 30-65\%.

Aim of our work was to investigate the prolactin (PL) level in patients treated with hemodialysis.

Methods. An open prospective, non-randomized study it was involved 43 patients with $C K D$ in the VD stage treated with hemodialysis. Criteria for inclusion of patients in the study were informed consent of the patient to participate in the study, treatment of $H D$ for more than three months, $K t / V>1.2$; vascular access - $A V$-fistula. The exclusion criteria were: refusal of the patient to participate in the study, liver cirrhosis, acute hepatitis $B, C$, hypothyroidism, acute coronary syndrome, stroke, pregnancy, patients with malignant neoplasms; those who systemically receive medications such as tricyclic antidepressants, monoamine oxidase inhibitors, reserpine, methyldopa, phenothiazine derivatives, antiemetic drugs (zocrama metoclopramide), dopamine synthesis inhibitors, and antipsychotics. All patients were evaluated for PL in serum.

Results. Patients treated with HD have reported an elevated PL level in 32 (74\%) patients. The level of serum $P L$ in patients treated with $H D$ was higher compared to the control group: $47.17 \pm 32.4$ versus $11.76 \pm 4.33 \mathrm{ng} / \mathrm{ml}(p<0.001)$. The violation of the menstrual cycle was $85 \%$ in the group of women with elevated PL compared with $20 \%$ in women with normal PL $(p<0.05)$. In groups of women and men with elevated $P L$ level, the $\mathrm{Hb}$ level was significantly lower $(p<0.05)$. It was established that the level of TL had a negative correlation with the level of $\mathrm{Hb}(r=-0.36 ; p=0,02)$ and a positive correlation between the level of TL and $C R P(r=0,32 ; p=0,03)$.

Conclusions. The prevalence of hyperprolactinemia in our study was $74 \%$. Violations of the menstrual cycle were significantly more common in women with hyperprolactinemia ( $85 \%$ vs. 20\%). The increase in the concentration of $P L$ has a negative correlation with the level of $\mathrm{Hb}$ and a positive correlation with the level of $C R P$, which suggests the involvement of $P B$ in the processes of chronic inflammation

Key words: chronic kidney disease, hemodialysis, prolactin.

Conflict of interest statement: all the authors declared no competing interests.

(C) I. Dudar, V. Savchuk, O. Loboda, Y. Gonchar, I. Shifris, V. Krot, 2018. All rights reserved Correspondence should be addressed to Irina Dudar: irina_d@ukr.net 
(с Дудар I.О., Савчук В.М., Лобода О.М., Гончар Ю.І., Шіфріс I.M., Крот В.Ф., 2018

УДК: 616.61-036.12-055.2:612.662.9]-085.38-07:618.344-07

\author{
І.О. Дудар, В.М. Савчук, О.М. Лобода, Ю.І. Гончар, І.М. Шіфріс, В.Ф. Крот
}

\title{
Рівень пролактину у пацієнтів з XXН V стадії, які лікуються гемодіалізом
}

\author{
Державна установа «Інститут нефрології НАМН України», м. Київ
} $30-65 \%$.

Резюме: Розповсюдженість гіперпролатинемії у пацієнтів, які лікуються гемодіалізом (ГД), становить

Метою нашої роботи було дослідити рівень пролактину (ПЛ) у пацієнтів з хронічною хворобою нирок (ХХН) V стадії, які лікуються ГД.

Матеріали та методи. Відкрите проспективне нерандомізоване дослідження за участю 43 пацієнтів 3 ХХН VД стадії, які лікуються гемодіалізом. Критеріями включення пацієнтів до дослідження були: інформована згода хворого прийняти участь у дослідженні, лікування ГД понад трьох місяців, Kt/V>1,2; судинний доступ ABфістула. Критеріями виключення були: відмова хворого від участі у дослідженні, цироз печінки, гострі гепатити $B, C$, гіпотиреоз, гострий коронарний синдром, гостре порушення мозкового кровообігу, вагітність, пацієнти 3 злоякісними новоутвореннями; ті хто, системно отримує такі медикаменти, як трициклічні антидепресанти, інгібітори моноамінооксидази, резерпін, метилдопу, похідні фенотіазину, протиблювотні препарати (зокреама метоклопрамід), інгібітори синтезу дофаміну, нейролептики. Всім хворим проводили визначення ПЛ в сироватці крові.

Результати. У хворих, які лікуються ГД констатовано підвищений рівень ПЛ у 32 (74\%) пацієнтів. Рівень ПЛ сироватки крові у хворих, які лікуються ГД, був вищим порівняно з групою контролю: 47,17 \pm 32,4 проти 11,76 \pm 4,33нг/мл (p<0,001). Порушення місячного ииклу склало 85\% у групі жінок з підвищеним рівнем ПЛ проти $20 \%$ у жінок з нормальним рівнем ПЛ ( $<0$,05). У групах жкінок та чоловіків з підвищеним рівнем ПЛ достовірно нижчий рівень $\mathrm{Hb}(p<0,05)$. Встановлено, що рівень ПЛ мав негативний кореляційний зв'язок з рівнем Hb (r=-0,36; $p=0,02)$ та позитивний кореляційний зв язок між рівнем ПЛ та СРБ (r=0,32; $p=0,03)$.

Висновки. Розповсюдженість гіперпролактинемії в нашому дослідженні склала 74\%. Порушення менструального циклу зустрічалося достовірно частіше у жінок з гіперпролактинемією (85\% проти 20\%). Підвищення концентрації ПЛ має негативний зв'язок з рівнем Нb та позитивний зв'язок з рівнем СРП, що дозволяє припускати причетність ПЛ до процесів хронічного запалення.

Ключові слова: хронічна хвороба нирок, гемодіаліз, пролактин.

Вступ. Згідно офіційних даних станом у 2017 році в Україні зареєстровано більш ніж 6,7 тис. хворих на хронічну хворобу нирок (ХХН), які отримують лікування гемодіалізом (ГД) [1]. За даними наукової літератури поширеність гіперпролактинемії у хворих на ХХН становить від $30 \%$ до 65\% [2, 3]. За умови ХХН продукція та елімінація пролактину (ПЛ) змінюються. Відмічають негативну кореляцію між рівнями швидкості клубочкової фільтрації (ШКФ) та ПЛ, індексом маси тіла (IMT) та ПЛ, рівнем фосфору і кальцію та ПЛ, а також між низьким рівнем альбуміну і гемоглобіну та ПЛ $[2,3]$.

Метою нашої роботи було дослідити рівень пролактину у пацієнтів з ХХН VД стадії, які лікуються гемодіалізом.

Матеріали та методи дослідження. Відкрите проспективне обсерваційне дослідження за участю 43 пацієнтів з ХХН VД стадії, які лікуються гемодіалізом.

\section{Дудар Ірина Олексіївна irina_d@ukr.net}

Критеріями включення пацієнтів до дослідження були: інформована згода хворого на участь у дослідженні, лікування ГД понад три місяці, $\mathrm{Kt} / \mathrm{V}>1,2$; судинний доступ АВ-фістула.

Критеріями виключення були: відмова хворого від участі у дослідженні, цироз печінки, гострі гепатити В, С, гіпотиреоз, гострий коронарний синдром, гостре порушення мозкового кровообігу, вагітність, злоякісні новоутворення, прийом трициклічних антидепресантів, інгібіторів моноамінооксидази, резерпіну, метилдопи, похідних фенотіазину, протиблювотних засобів (зокреама метоклопрамід), інгібіторів синтезу дофаміну, нейролептиків.

Верифікація діагнозу ХХН та обсяг обстежень проведені за рекомендаціями K/DOQI (Kidney Disease OutcomesQualityInitiative, 2002); наказами MO3 України №65/462 від 30.09.2003, № 593/2004, № 23/2005, № 43/2006, № 330/2007, протоколами надання медичної допомоги за спеціальністю "Нефрологія» (наказ МО3 № 593/2004). Крім того, всім хворим визначали рівні ПЛ, тиреотропного гормону (ТТГ). Також проведене опитування пацієнток 3 приводу наявних порушень менструального циклу.

Рівні ПЛ та ТТГ визначали імунохімічним методом 3 електрохемілюмінесцентною детекцією. Результати порівнювались з показниками рівня ПЛ 
у 20 здорових осіб, які за віком відповідали групі обстежуваних пацієнтів.

Забір крові на визначення рівня ПЛ проводився до початку сеансу ГД не пізніше ніж через 2 години після пробудження зранку, напередодні були виключені фізичні, психоемоційні перевантаження, статеве життя.

Після обстеження пацієнти, які лікуються ГД, в залежності від статі та рівня ПЛ були розділені на 4 групи: жінки 3 підвищеним та нормальним рівнем ПЛ, чоловіки з підвищеним та нормальним рівнем ПЛ.

Під час виконання роботи дотримані принципи біоетики, законодавчих норм та вимог щодо проведення біомедичних досліджень.

Статистичне опрацювання результатів дослідження проводили за допомогою Microsoft Office Excel 2006 та пакету STATISTICA for Windows 6.0 (Statsoft Inc., США).
Результати дослідження. Середній вік хворих становив 41,2 \pm 9,1 р. (від 27 до 70 років). За статтю розподіл хворих був наступним: 20 хворих чоловічої (47\%) та 23 хворих жіночої статі (53\%). Тривалість лікування ГД становила від 4-ьох місяців до 5,8 $(2,57 \pm 1,6)$ років, рівень С реактивного білку (СРБ) 8,93 \pm 5,3 мг/л, феритин 233 (168; 423) нг/мл, \% насичення трансферину (\% НСТ) $21,86 \pm 48,2 \%$, IMT $23,3 \pm 3,43$ кг/м2, ТТГ 2,59 \pm 0,56 мМО/л, гемоглобін (Нв) 93,6 \pm 13,6 г/л. За нозологією недіабетичні захворювання складали 93\% ( $\mathrm{n}=40)$, діабетичні захворювання 7\% $(\mathrm{n}=3)$. Підвищений рівень ПЛ був у $32(74,4 \%)$ пацієнтів, з них жінок - 17 (53\%), чоловіків - 15 (47\%).

Клініко-лабораторні показники хворих, які лікувалися ГД представлені у таблицях 1-2.

Рівень сироваткового пролактину у ГД хворих порівняно з групою контролю

\begin{tabular}{|c|c|c|c|}
\hline Показник & $\begin{array}{c}\text { Контроль } \\
\mathbf{n}=\mathbf{2 0}\end{array}$ & $\begin{array}{c}\text { Хворі } \mathbf{3} \text { XXH } \\
\mathbf{n}=\mathbf{4 3}\end{array}$ & $\mathbf{p}$ \\
\hline Пролактин, нг/мл & $11,76 \pm 4,33$ & $47,17 \pm 32,4$ & $<0,001$ \\
\hline
\end{tabular}

Клінічна характеристика досліджуваних пацієнтів залежно від статі

Таблиия 2

\begin{tabular}{|l|c|c|}
\hline \multicolumn{1}{|c|}{ Показник } & $\begin{array}{c}\text { чоловіки } \\
\mathbf{n = 2 0}\end{array}$ & $\begin{array}{c}\text { жінки } \\
\mathbf{n = 2 3}\end{array}$ \\
\hline Гемоглобін, г/л & $98,3 \pm 3,57^{*}$ & $89,59 \pm 2,22^{*}$ \\
\hline Вік, роки & $43,55 \pm 2,27$ & $39,2 \pm 1,57$ \\
\hline Тривалість ГД, роки & $2,16 \pm 0,26$ & $2,93 \pm 0,38$ \\
\hline ІМТ, кг/м ${ }^{2}$ & $24,05 \pm 0,80$ & $22,78 \pm 0,67$ \\
\hline СРБ, мг/л & $8,15 \pm 1,1$ & $9,61 \pm 1,17$ \\
\hline Феритин, нг/мл & $270,6 \pm 28,5$ & $297,3 \pm 36,6$ \\
\hline \%НСТ & $23,4 \pm 1,15$ & $20,52 \pm 0,87^{*}$ \\
\hline ТТГ, мМО/л & $2,23 \pm 0,16$ & $2,91 \pm 0,13$ \\
\hline Пролактин, нг/мл & $34,22 \pm 5,14$ & $58,44 \pm 7,42^{*}$ \\
\hline
\end{tabular}

Примітка: дані представлені у вигляді $\mathrm{M} \pm \mathrm{m},{ }^{*} \mathrm{p}<0,05$

Як представлено у таблиці 2, рівень Нв та \% НСТ достовірно вищий у чоловіків, ніж у жінок, що зумовлено скоріше за все наявними менструальними крововтратами у жінок враховуючи їх середній вік 39,2 \pm 1,6 років. Достовірно вищою була концентрація ПЛ у жінок, які лікуються ГД, порівняно з чоловіками.
Порушення менструального циклу відмічалось у $57 \%$ жінок (13 осіб).

У подальшому був проведений аналіз у групах жінок та чоловіків з нормальним рівнем ПЛ та підвищеним рівнем ПЛ (табл. 3).

Таблиия 3

Аналіз показників серед чоловіків та жінок у групах з підвищеним та нормальним ПЛ

\begin{tabular}{|l|c|c|c|c|}
\hline \multirow{2}{*}{ Показник } & \multicolumn{2}{|c|}{ жінки } & \multicolumn{2}{c|}{ чоловіки } \\
\cline { 2 - 5 } & $\begin{array}{c}\text { підвищеним ПЛ } \\
\mathbf{n = 1 8}\end{array}$ & $\begin{array}{c}\mathbf{3} \text { нормальним ПЛ } \\
\mathbf{n = 5}\end{array}$ & $\begin{array}{c}\text { підвищеним ПЛ } \\
\mathbf{n = 1 5}\end{array}$ & $\begin{array}{c}\text { нормальним ПЛ } \\
\mathbf{n}=\mathbf{5}\end{array}$ \\
\hline Гемоглобін, г/л & $85,0 \pm 1,5$ & $105,8 \pm 2,9^{*}$ & $91,1 \pm 2,5$ & $115,0 \pm 6,7^{* *}$ \\
\hline Вік, роки & $37,8 \pm 1,43$ & $44,2 \pm 4,86$ & $44,2 \pm 2,93$ & $41,83 \pm 3,47$ \\
\hline
\end{tabular}


Продовження таблиці 3

\begin{tabular}{|l|c|c|c|c|}
\hline \multirow{2}{*}{\multicolumn{1}{|c|}{ Показник }} & \multicolumn{2}{c|}{ жінки } & \multicolumn{2}{c|}{ чоловіки } \\
\cline { 2 - 5 } & $\begin{array}{c}\text { підищеним ПЛ } \\
\mathbf{n}=\mathbf{1 8}\end{array}$ & $\begin{array}{c}\mathbf{3} \text { нормальним ПЛ } \\
\mathbf{n = 5}\end{array}$ & $\begin{array}{c}\text { підвищеним ПЛ } \\
\mathbf{n}=\mathbf{1 5}\end{array}$ & $\begin{array}{c}\text { нормальним ПЛ } \\
\mathbf{n}=\mathbf{5}\end{array}$ \\
\hline $\begin{array}{l}\text { Тривалість } \\
\text { ГД, роки }\end{array}$ & $2,99 \pm 0,47$ & $2,70 \pm 0,59$ & $2,12 \pm 0,34$ & $2,25 \pm 0,43$ \\
\hline ІМТ, кг/м & $22,27 \pm 0,8$ & $24,6 \pm 0,74$ & $23,6 \pm 1,07$ & $25,0 \pm 1,0$ \\
\hline СРБ, мг/л & $10,66 \pm 1,37$ & $5,08 \pm 1,24$ & $9,5 \pm 1,35$ & $5,0 \pm 1,15$ \\
\hline Феритин, нг/мл & $320,83 \pm 44,6$ & $212,8 \pm 34,6$ & $297,4 \pm 37,6$ & $208,0 \pm 24,2$ \\
\hline НСТ, \% & $20,77 \pm 1,05$ & $19,6 \pm 1,43$ & $22,57 \pm 1,29$ & $25,3 \pm 2,33$ \\
\hline ТТГ, мМО/л & $3,14 \pm 0,11$ & $2,06 \pm 0,12^{*}$ & $2,25 \pm 0,25$ & $2,17 \pm 0,23$ \\
\hline Пролактин, нг/мл & $69,38 \pm 7,64$ & $19,08 \pm 1,94^{*}$ & $43,07 \pm 5,92$ & $13,55 \pm 0,51^{* *}$ \\
\hline $\begin{array}{l}\text { Порушення } \\
\text { ментсруального циклу }\end{array}$ & $12(85 \%)$ & $1(20 \%)^{*}$ & & - \\
\hline
\end{tabular}

* $\mathrm{p}<0,05$ між групами жінок з підвищеним та нормальним рівнями ПЛ

**p $<0,05$ між групами чоловіків з підвищеним та нормальним рівнями ПЛ

3 табл. 3 видно, що серед жінок у групі з підвищеним рівнем ПЛ достовірно вищим був рівень ТТГ 3,14 \pm 0,11 мМО/л проти 2,06 $\pm 0,12 \mathrm{мMO/л}$ $(\mathrm{p}<0,05)$ та нижчим рівень Нв 85,0 \pm 1,5 г/л проти $105,8 \pm 2,9$ г/л $(\mathrm{p}<0,05)$. У Більшої частини жінок $(85 \%)$ з підвищеним рівнем пролактину були зафіксовані порушення менструального циклу. У чоловіків з підвищеним ПЛ був нижчим рівень Нв
$91,1 \pm 2,5$ г/л проти $115,0 \pm 6,7$ г/л $(\mathrm{p}<0,05)$. Групи були ідентичними за віком, статтю, тривалістю лікування ГД, IМТ, \%НСТ, феритином, СРБ.

Наступним етапом нашої роботи було вивчення зв'язку між рівнями ПЛ і Нb. Встановлено, що ПЛ мав негативний кореляційний зв'язок з рівнем $\mathrm{Hb}(\mathrm{r}=-0,36 ; \mathrm{p}=0,02)$ (рис. 1$)$.

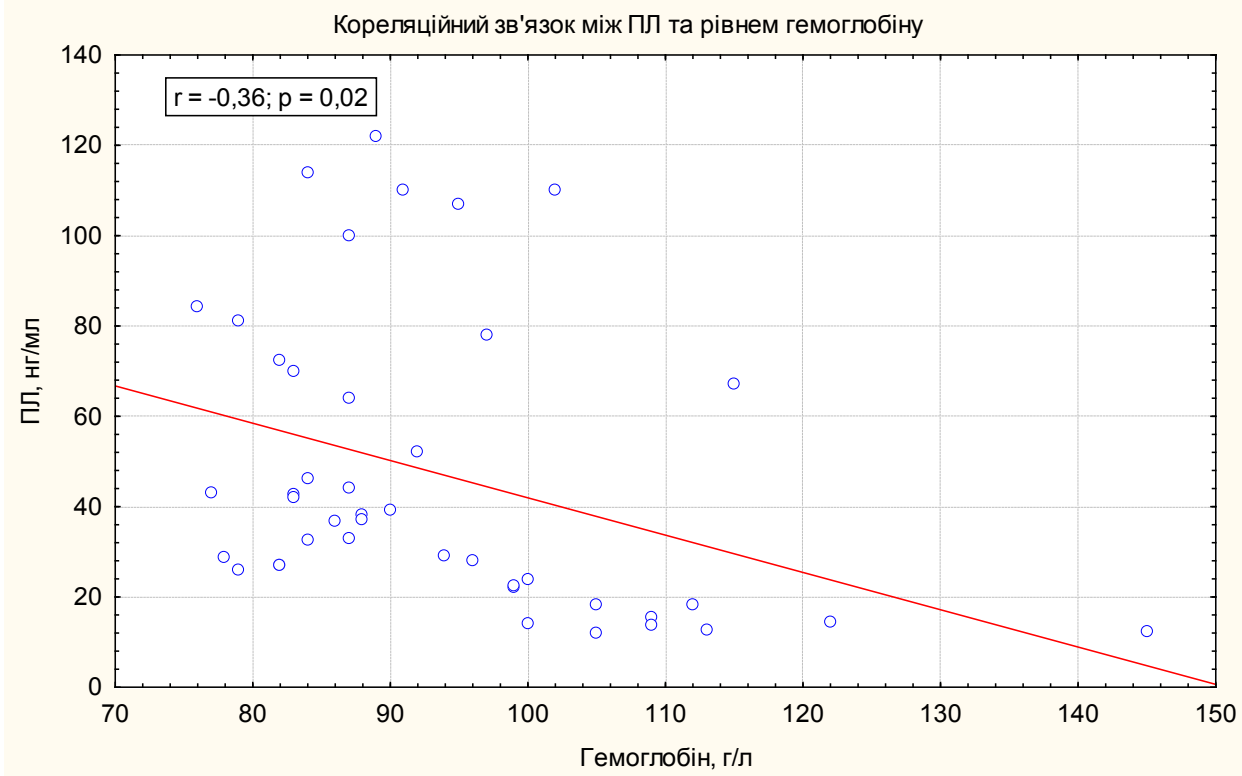

Рис. 1. Кореляційний зв’язок між рівнем ПЛ та рівнем гемоглбіну в крові хворих, які лікуються ГД.

Встановлено прямий кореляційний зв'язок між рівнем ПЛ та СРБ ( $\mathrm{r}=0,32 ; \mathrm{p}=0,03)$ (рис. 2$)$.

Обговорення. В нашому дослідженні підвищений рівень ПЛ було констатовано у 74\% пацієнтів, що перевищує розповсюдженість (30-60\%) гіперпролактинемії у хворих на Гд за даними літератури $[2,3]$. Це може бути обумовлене невеликою популяцією пацієнтів, яка досліджувалася, та потребує більш масштабних досліджень. 


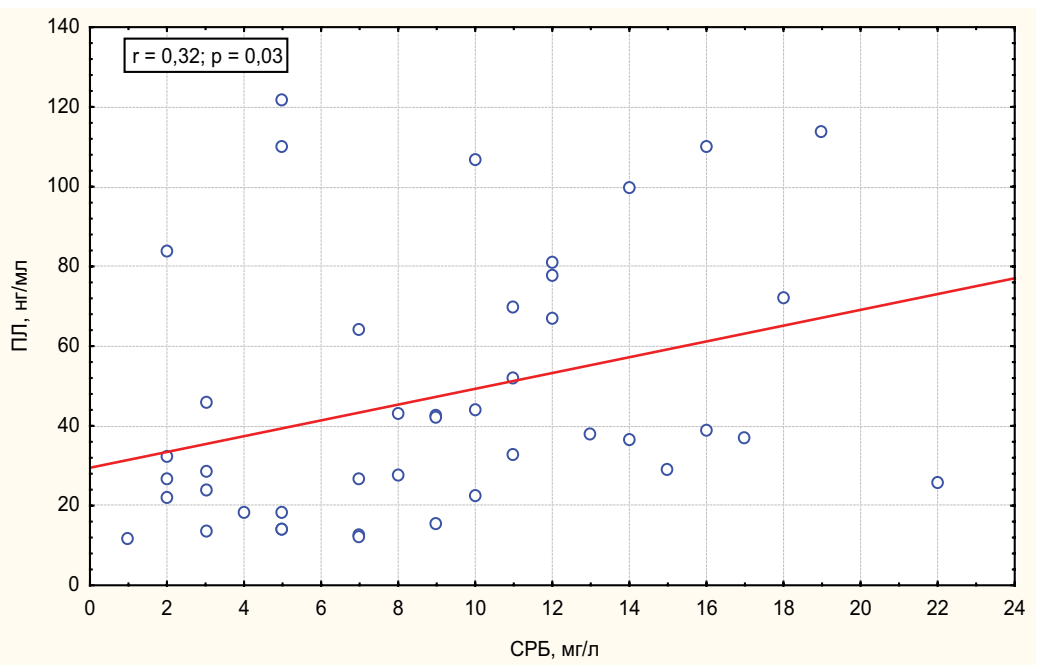

Рис. 2. Кореляційний зв'язок між рівнем ПЛ та рівнем СРБ в крові хворих, які лікуються ГД.

У пацієнтів з ХХН помірна ГПЛ пов'язана 3 порушенням виведення нирками ПЛ, розладами центральної регуляції секреції ПЛ та використанням деяких ліків [2, 3]. Доведено, що у хворих, які лікуються ГД, приблизно у 3 рази вища секреція ПЛ порівняно зі здоровими особами, що, імовірно, обумовлено зниженням здатності дофаміну пригнічувати секрецію ПЛ за рахунок конкурентного зв'язування уремічних токсинів з дофаміном, рецепторами до дофаміну або з пострецепторними порушеннями. Медикаментозно-індукована ГПЛ виникає при застосуванні метоклопраміду, рисперитону, феритиазінів за рахунок антидофамінових ефектів цих препаратів. У середньому при прийомі антипсихотичних ліків ГПЛ зустрічається у $38-81 \%$ пацієнтів, верапамілу $-8,5 \%$, оральних контрацептивів з високими дозами естрогенів - 12-30\% [4].

Встановлено, що при ГПЛ відмічається порушення пульсуючої секреції гонадотропних гормонів (ГТГ), зокрема зміна частоти імпульсів лютеїнізуючого гормону (ЛГ), резистентність яєчникових рецепторів до ЛГ, зменшення синтезу прогестерону клітинами гранульози, пригнічення залежної від фолікулостимулюючого гормону оваріальної ароматази, що викликаэ зниження продукції естрогену. У чоловіків ГПЛ веде до посилення проявів гіпогонадизму, дефіциту тестостостерону (Тc), який пов'язаний зі зростанням індексу маси тіла (IMT), виникненням атеросклеротичної бляшки, запаленням, серцево-судинними захворюваннями (СС3), смертністю, виникненням гінекомастії і сексуальної дисфункції [4]. У жінок ГПЛ викликає галакторею і порушення менструального циклу, часто аменорею. До того ж, ПЛ регулює секрецію наднирникових андрогенів, тому до 40\% хворих з ГПЛ мають порушення секреції і метаболізму андрогенів, що веде до клінічних проявів гіперандрогенії (гірсутизму і акне), формуванню склерокістозних яєчників [4].

На даний час мало відомо про наслідки ГПЛ у пацієнтів з ХХН. У деяких дослідженнях відмічали негативну кореляцію між рівнями ПЛ та швидкістю клубочкової фільтрації, ПЛ та рівнем фосфору і кальцію, ПЛ та низьким альбуміном і ПЛ та рівнем гемоглобіну $(\mathrm{Hb})$ [3]. In vitro ПЛ моделював запальну реакцію, стимулював адгезію мононуклеарних клітин до ендотелію та посилював проліферацію м'язових клітин у судинах. В одному з досліджень показано збільшення ризику серцевосудинних подій у недіаліалізних пацієнтів на $27 \%$ на кожні на 10 нг/мл підвищення ПЛ (відношення ризиків [HR], 1,27, довірчий інтервал 95\% [95\% ДI], 1,17-1,38). Аналогічним чином, ризик смертності від усіх причин і ССЗ у пацієнтів на ГД зріс на $12 \%$ (HR, 1,12, 95\% ДI, 1,06-1,17) i 15\% (HR, 1,15, 95\% ДI, 1,08-1,21), відповідно. Рівні ПЛ, безпосередньо пов'язані з ендотеліальною дисфункцією/ жорсткістю міокарду, підвищеним ризиком серцево-судинних подій при ХХН. Підвищена експресія рецепторів ПЛ була виявлена в атеросклеротичних бляшках людини. У попередніх дослідженнях на свинях продемонстровано регіональні вазоконстрикторні ефекти ПЛ через $\beta 2$-адренергічні рецептори та оксид азоту, чим і пояснюють підвищений серцево-судинний ризик при ГПЛ. Окисний стрес пов'язаний з розщепленням ПЛ на антиангіогенну, проапоптотичну і прозапальну $16-\mathrm{kD}-$ форму, яка може ініціювати ускладнення пов'язані з атеросклерозом. Гіперпролактинемія також може бути наслідком зниженої допамінергічної активності, яка приводить до вивільнення норепінефрину і несприятливо впливає на ендотеліальну дисфункцію, сприяє гіпертрофії міокарду, АГ та ін. СС $[3,5]$. Часто підвищення рівня ПЛ відмічається при гіпертонічній хворобі, ішемічних інсультах, транзиторних ішемічних атаках, прееклампсії, під час гострої фази коронарного синдрому, відіграє роль у розвитку серцевої недостатності, супроводжує післяпологову кардіоміопатію [5]. Рівні ПЛ часто передбачали основні серцево-судинні події у чоловіків з еректильною дисфункцією. Кілька не- 
давно проведених досліджень демонструють, що підвищений ПЛ приймає участь у формуванні резистентності до інсуліну.

ГПЛ може посилювати прояви гіпогонадизму. Корекція іiі бромкриптином відновлює менструальну функцію. При тривалій медикаментозно-індукованій ГПЛ з гіпогонадизмом та остеопорозом рекомендоване призначення препаратів естрогену чи Тс [6].

Виявлені у ГД хворих негативний кореляційний зв'язок рівнів гемоглобіну та ПЛ та позитивний кореляційний зв’язок СРБ з ПЛ вказують на можливу роль, яку відіграють гормональні порушення у діалізних хворих в розвитку анемії та процесів хронічного запалення. Все це потребує подальшого вивчення.

\section{Висновки:}

Розповсюдженість гіперпролактинемії у хворих на XXН V ГД становить $74 \%$.
Порушення менструального циклу діагностується достовірно частіше у жінок 3 гіперпролактинемією (85\% проти 20\%), що свідчить про пригнічення оваріально-менструального циклу та необхідності корекції та подальшого вивчення.

Підвищення концентрації ПЛ має негативний зв'язок з рівнем Нь та позитивний зв'язок з рівнем СРП, що вказує на причетність ПЛ до процесів хронічного запалення.

Конфлікт інтересів: автори заявляють про відсутність конфлікту інтересів.

\section{Інформація про внесок кожного учасника:}

I. O. Дудар: концепція та дизайн дослідження,

B. М. Савцук: аналіз отриманих даних,

O.M. Лобода: аналіз отриманих даних,

Ю.I. Гончар: оформлення тексту роботи,

I.M. Wiфpic: оформлення тексту роботи, B. Ф. Kрот: підготовка статті до друку.

\section{Література (References):}

1. Kolesnyk $M O$, redaktor. Natsionalnyi reiestr khvorykh na khronichnu khvorobu nyrok ta patsiientiv z hostrym poshkodzhenniam nyrok: 2017 rik. Kyiv; 2018. 183 s. [In Ukrainian].

2. Palmer BF. Sexual dysfunction in men and women with chronic kidney disease and end-stage kidney disease. ACKD. 2003;10(1):48-60. doi: 10.1053/ jarr.2003.50003

3. Nehru D, Kandasamy S, Chandramouli RK, Muthumani L. Evaluation of serum prolactin level in chronic kidney disease. Asian J Pharm Clin Res. 2016; 9(4):201-203.

4. Melmed S, Casanueva FF, Hoffman AR, Kleinberg DL, Montori VM, Schlechte JA, Wass JAH.
Diagnosis and treatment of hyperprolactinemia: an Endocrine Society clinical practice guideline. J. Clin. Endocrinol. Metab. 2011;96(2):273-88. doi: $10.1210 /$ jc.2010-1692.

5. Lakshmi D, Meera KS, Mahesh E. Serum prolactin level and inflammation in chronic kidney disease. International Journal Of Biochemistry Research \& Review. 2016;14(1):1-9. doi: 10.9734/ IJBCRR/2016/29218

6. Lo JC, Beck GJ, Kaysen GA. Hyperprolactinemia in end stage renal disease and effects of frequent hemodialysis. Hemodial Int. 2017;21(2):190-196. doi: $10.1111 /$ hdi.12489. 